Article

\title{
Empowering English Language Learners through Digital Literacies: Research, Complexities, and Implications
}

\author{
Chang Yuan *, Lili Wang and Jessica Eagle \\ Teacher Education and Learning Sciences, North Carolina State University, Raleigh, NC 27695, USA; E-Mails: cyuan@ncsu.edu \\ (C.Y.), Iwang52@ncsu.edu (L.W.), jleagle@ncsu.edu (J.E.)
}

* Corresponding author

Submitted: 15 December 2018 | Accepted: 31 January 2019 | Published: 11 June 2019

\begin{abstract}
In the context of an increasingly global society and rapidly changing technology, English Language Learners (ELLs) need support to develop digital literacies to prepare for a future in which learning new technology is an intuitive process. In the past few decades, technological advances have been shifting how information is produced, communicated, and interpreted. The Internet and digital environments have afforded a broader range of opportunities for literacy practices to take place. Technology has transformed the social practices and definitions of literacy, which leads to transformative implications for the teaching and learning environments facing ELLs. Despite immigrants' attraction to the US, the tension between the public school system and emergent bilingual students has garnered broad attention. There is a need for a more appropriate teaching pedagogy that embraces the cultural identities of ELLs, and empowers ELLs as critical consumers and producers of information. Though complex, the authors advocate for examining this issue using an asset perspective rather than a deficit lens. Using the sociocultural perspective of learning and critical theory, this paper aims to define and conceptualize ELL learning, establish a shared vision of digital literacies, and review the literature on how practices of digital literacies empower ELLs to become active learners. In the final section, implications and future research directions are articulated in order to move the digital literacy field forward.
\end{abstract}

\section{Keywords}

critical theory; digital divide; digital literacies; English language learners

Issue

This article is part of the issue "Critical Perspectives on Digital Literacies: Creating a Path Forward", edited by Hiller A. Spires (North Carolina State University, USA).

(C) 2019 by the authors; licensee Cogitatio (Lisbon, Portugal). This article is licensed under a Creative Commons Attribution 4.0 International License (CC BY).

\section{Introduction}

In the context of an increasingly global society and rapidly changing technology, English Language Learners (ELLs) need support to develop digital literacies to prepare for a future in which learning new technology is an intuitive process. Technological advances are perpetually shifting how information is produced, communicated, and interpreted. In classrooms of the past, teachers and students relied on tangible tools to access information, and practice reading, writing, speaking, and listening; in the 21st century classroom, the Internet and digital environments have afforded a broader range of opportunities for literacy practices to take place.

This emerging phenomenon has influenced how stakeholders perceive what it means to be literate in the 21st century. In the US, the Common Core State Standards Initiative (CCSS) depicts 21st century learners as strategic and capable users in the digital environment within their social practice of literacy. Students must proficiently synthesize online and offline information and wisely select digital tools (National Governors Association Center for Best Practices, 2010). Similarly, the International Society for Technology in Education (ISTE) con- 
siders a student an "empowered learner, digital citizen, knowledge constructor, innovative designer, computational thinker, creative communicator, and global collaborator" (2016). Thus, technology has transformed the social practices and definition of literacy.

According to the National Center for Education Statistics ([NCES], 2018), the population of ELLs in public school increased from two million in 1990 to 4.8 million in 2015 and is expected to represent a quarter of total learners in 2025 (Capps et al., 2005). Despite immigrants' attraction to the US, the tension between the public school system and emergent bilingual students has garnered broad attention (Gándara, 2015). Data reveals that a consistent achievement gap exists between ELLs and their non-ELLs peers on standardized test scores (NCES, 2017a). Attributing this to systemic inequity, many sociocultural and critical theorists note that the "white privilege pedagogy" (Margolin, 2015, p. 1), slowly responsive teacher education programs, and the shortage of teachers of color are interwoven dynamically and therefore contribute to the status quo of ELLs (Haddix, 2016).

There is a need for a more appropriate teaching pedagogy that embraces the cultural identities of ELLs, and empowers ELLs as critical consumers and producers of information. Though complex, the authors advocate for examining this issue using an asset (Hakuta \& Garcia, 1989) perspective rather than a deficit lens (Eller, 1989). Accordingly, this article proposes digital teaching pedagogies that promote digital literacies as most urgent and necessary for ELLs.

Using the sociocultural perspective of learning and critical theory, this paper aims to define and conceptualize ELL learning, establish a shared vision of digital literacies, and review the literature on how practices of digital literacies empower ELLs to become active learners. In the final section, implications and future research directions are articulated for researchers in order to move the digital literacy field forward.

\section{English Language Learners in the United States}

Since the end of the Cold War, the United States has become a top destination of international immigrants. As a result, in the past decades, millions of emergent bilingual students entered the US public school system and were taught by teachers who are predominantly white, English-monolingual, middle-class females (NCES, 2017b). With an intent to fuse these newcomers in the "melting pot," English-only programs are broadly implemented in the K-12 classrooms (García \& Kleifgen, 2018). However, as García and Kleifgen argued, the monolingual way of teaching is leading to and reinforcing inequity in education in that emergent bilinguals are not only deprived of their cultural and linguistic assets (Boykin, Tyler, \& Miller, 2005) but also encounter marginalized identities (Norton, 2016). As the achievement gap persists in the United States, finding effective ways to address the tension is emergent and urgent.

\subsection{Definition of English Language Learners}

Generally speaking, the term English language learners refers to learners of English as a new language or an additional language. For the purpose of discussing the disparities of academic achievement between ELLs and their native English speakers in the United States, we adopted the definition that the US Department of Education (2016) provided: English language learners are those students who are:

Age 3-21, enrolled in elementary or secondary education, born outside of the United States or speaking a language other than English in their homes, and whose difficulties in speaking, reading, writing, or understanding the English language may be sufficient to deny the individual 1) the ability to meet the challenging State academic standards; 2) to successfully achieve in classrooms where the language of instruction is English; or 3) the opportunity to participate fully in society. (US Department of Education, 2016, p. 43)

With this "academic English" (García \& Kleifgen, 2018, p. 4) focused definition, we are now able to understand, explore, and interrogate the achievement gap that occurs in classrooms locally and nationally.

\subsection{The Achievement Gap between ELLs and Native English Speakers}

Despite frequent discourse on the academic achievement gap in US education (Ladson-Billings, 2006), the enrollment of the K-12 ELL population continues to increase and contribute to tensions between ELLs and their native English speaking peers. According to the National Governors' Association (2017), the achievement gap is "a matter of race and class. Across the US, a gap in academic achievement persists between minority and disadvantaged students and their white counterparts" (p. 1). In a US national study quantifying the achievement gap for reading proficiency, 30.4 percent of students scored at the level of proficient or better, whereas the percentage dropped to just 5.6 among ELLs (National Assessment of Educational Progress, 2009). Although students' standardized exam scores across all races and ethnicities have steadily increased since 2015, the gaps between ELLs and non-ELLs were not eliminated (Musu-Gillette et al., 2017).

\subsection{Sociocultural Perspective of Learning and Language}

Prevailing in the 1960s, the deficit theory suggested that students' low achievements are due to their "pathological lifestyles [which] prohibits the study of children of color" (Coleman et al., 1966, p. 43). This early perspective was later challenged by sociocultural theorists (e.g., Cummins, 1996; Delpit, 1988; Heath, 1983) who con- 
tended that the achievement gap is in fact a result stemming from complex social interactions between individuals and their surroundings such as communities, families, social institutes subjected on education. Criticizing scholars who solely view students learning and attainment as a process and result of individual cognitive ability, sociocultural researchers claim that the context and the interactive relationship between learners and the social situations are central to learning.

Rooted in Russian psychologist Lev Vygotsky's constructivist theory (1978), the sociocultural perspective of learning views social engagements as the essence which "provides the most effective and appropriate context for curriculum learning to take place" (Gibbons, 2006, p. 22). Based on this understanding, Lantolf and Thorne (2007) tailored the sociocultural theory to the field of second language acquisition (SLA) in which how to develop language learners' academic participation and interaction in the culture of schools becomes the major issue.

Many researchers and educators have studied and explored the affordances of culturally inclusive teaching in education, to whom, the multicultural background of minority learners is in fact the funds of knowledge (Moll, Amanti, Neff, \& Gonzalez, 1992). Heath's longitudinal ethnographic work Ways with Words (1983) revealed how historical roots and social and cultural practices contributed to the so-called academic failures of the students coming from two communities, and how these failures were addressed through culturally related pedagogy (Au \& Jordan, 1981; Gay, 2002) in the classroom.

\subsection{Critical Theory and Its Application in English Language Learning}

Maintaining "an emphasis on the social," critical lens moves further to "analyse, interrogate, challenge, and change forms of oppression and privileging of certain groups in society" (Mills, 2016, p. 36). Developed by the Frankfurt School, critical theory is an "approach to cultural criticism and social philosophy" (p. 46) that focuses on the superstructure particularly including the ideologies that shape social action, the role of dialogue and reason in social life, and a greater reflection on the system of constraints and the dialectical critique of political economy (Mills, 2016). In education, a critical orientation focuses on disrupting the reproduction of inequity in the school system, advocates the necessity of critiquing "neutrality" (Apple, Au, \& Gandin, 2009), and argues for an education reconstruction (Fairclough, 1989).

From critical perspectives, ELLs are systemically positioned as the oppressed through the discourse and interactions in the English monolingual classroom. Given the power relations in schools where ELLs are "members of particular discipline-related discourse communities, and learn to control the specific registers and genres of curriculum-related subjects" (Gibbons, 2006, p. 44), researchers noticed some ELLs "participate in a...disempowered manner" (Toohey, 1999, p. 34) and ar- gued that it is necessary to "nurture both intellect and identity equally in ways that challenge coercive power relations" (Cummins, 1996). Digital literacy practice in the classroom holds its promise in empowering ELLs.

\section{Digital Literacies}

\subsection{An Evolving Terminology in the Context of a Digital World}

It is well-acknowledged that digital literacy has become increasingly essential for individuals to be successful in living, learning and working in the context of the farreaching digitalization of society. As a recent UNESCO Broadband Commission for Sustainable Development ([BCSD], 2017) report stated:

Digital technologies now underpin effective participation in key areas of life and work. In addition to technology access, the skills and competencies needed to make use of digital technology and benefit from its growing power and functionality have never been more essential. (p. 4)

The field of digital literacy is continuously evolving, in response to technological advancements and the corresponding social and cultural impacts (Dore, Geraghty, \& O'Riordan, 2015). Various domains contributing to the concept have resulted in a variety of terms proposed in the literature, yet reaching no consensus. Most commonly used terminology refers to digital "skills," "competencies," "aptitudes," "knowledges," "understandings," "dispositions," "thinking" (BCSD, 2017, p. 23), "fluency," "capacities," "intelligence" (Brown, 2018, p. 52), and literacies. Among these terms, skills, literacies, and competencies are most relevant and appropriate in the discussions of education in the digital landscape (Dore et al., 2015), being used interchangeably.

Literacy or literacies has been established as the most frequently used term (Dore et al., 2015) that involves the multiplicity of "knowledge, attitudes and skills" (p. 12). Taking over "online," "networked," or "computer-based" (p. 11), "digital" is used to denote information and media technology featured in many social and cultural aspects of life (Dore et al., 2015). The notion of digital literacies incorporates "basic functional digital skills" to access and use digital devices and applications, "generic digital skills" that enable users to use digital technologies in "meaningful and beneficial ways" ( $p$. 27), alongside the "critical information literacies" (p. 32) which is part of "high level skills" (p. 30) emphasizing the capacity to critically consume information (BCSD, 2017).

The current concept of digital literacies, depending on various contributing domains and contexts, encompasses several overlapping elements of ICT literacy (ETS, 2007), information literacy (Zurkowski, 1974), media literacy (Dore et al., 2015), and visual literacy (Fransecky \& Debes, 1972; Lemke, 2002). 
The fluid and evolving nature of digital literacies has generated a range of definitions attempting to clarify what it means to be digitally literate since the term was conceived. For this reason, we present a brief chronology for definitions of digital literacies and highlight a framework that situates our argument for ELL empowerment.

\subsection{Definitions of Digital Literacies}

Paul Gilster (1997), in his book Digital Literacy, first published the term "digital literacy" and provided a definition as the "ability to understand and use information in multiple formats from a wide range of sources when it is presented via computers" (p. 1). Rather than merely focusing on basic technical skills, Gilster's notion emphasized reflective competence as an essential element of digital literacy.

Digital literacies have been continuously reconceptualized as new waves of digital innovations arose with new digital features that shaped all aspects of our lives. Ferrari (2012) stated:

Being digitally literate implies the ability to understand media (as most mediums are digitalized), to search and think critically about retrievable information (with the widespread use of the Internet) and be able to communicate with others through a variety of digital tools and applications. (p. 16)

The Battelle for Kids (2019) has described what students should develop in order to live in a technology and mediadriven environment:

People in the 21st century live in a technology and media-driven environment, marked by various characteristics, including 1) access to an abundance of information, 2) rapid changes in technology tools, and 3) the ability to collaborate and make individual contributions on an unprecedented scale. Effective citizens and workers of the 21st century must be able to exhibit a range of functional and critical thinking skills related to information, media and technology. (p. 5)

\subsection{Authentic Digital Literacy Practice Within and Outside ELL Classrooms}

Rooted in the "cultural heritage" and "media" ecosystem, digital literacy frameworks in the United States tend to foreground educational empowerment, enabling learners to "become more effective students, better creators, smarter information consumers, and more influential members of their community" (Alexander, Becker, Cummins, \& Giesinger, 2017, p. 11).

American scholars Spires and Bartlett (2012) developed a framework that categorizes the cognitive and social processes associated with digital literacies into three components: (a) locating and consuming digital content, (b) creating digital content, and (c) communicating dig- ital content. This framework, however, does not mean a user only focus on one component in a digital literacy activity; "in authentic digital literacy contexts, however, users traverse among these practices in a recursive manner" (p. 9). Another overarching theme is that learners should develop skepticism toward digital content, so as to proactively locate, create and communicate digital content that is credible and reliable, rather than passively receive digital information.

The characteristics of digital literacies (critical, multimodal and participatory) enable an authentic learning environment that empowers ELLs to be active participants who take student autonomy and ownership of learning, as well as developing English competencies within and outside the classroom. For instance, research by Tour (2012) revealed how the cultural contexts, critical thinking, and the operational English competencies (3D model; Durrant \& Green, 2000) along with technoliteracy manifested themselves in the instruction in ELL classrooms. The study has shown that ELLs do not learn technoliteracy automatically while learning English, calling for promoting digital literacy acquisition of ELLs.

Consequently, the integration of digital literacies, as part of innovative teaching pedagogies, can be leveraged to disrupt the power dynamics of a traditional English monolingual classroom, bringing cultural inclusiveness and closing the gaps between ELLs and their native English-speaking counterparts. Drawing upon a combined framework of the aforementioned concept of educational empowerment (Alexander et al., 2017) and categorization (Spires \& Bartlett, 2012) of digital literacies, the next section examines the literature on how digital literacies effectively empower ELLs in their learning and living.

\section{Empowering ELLs in the United States Through Digital Literacies}

For ELLs, digital literacies provide unique conditions for increasing literacy in general and is therefore an important consideration for educational equity. Barone (2006) suggested literacy gaps have a direct influence on the academic achievement gap. Digital literacies are a mediator for participation in a global technology economy. School systems have responded to such mandates by investing in the use of technology for instruction and assessment in core content areas. To ensure that students are afforded adequate classroom opportunities to acquire digital literacies, teachers are often evaluated on the extent to which they implement technology in their daily instruction. In this section, we examine how practices of digital literacies empower ELLs to become active participants in the co-creation of knowledge alongside their native English speaking peers.

\subsection{Locating and Consuming Digital Content}

Being able to locate and consume digital content is key to success in navigating the Internet. Part of the allure 
of digital literacies is from the autonomy students are experiencing when they are navigating the wealth of information accessed using the digital interface; it is empowering to know how to and independently utilize methods for facilitating one's own inquiries. With access to the Internet, digitally literate ELLs are in a particularly powerful position to transgress the traditional roles of their native-speaking instructors and peers as authority and transmitters of information. Through the process of sifting through unreliable or irrelevant information and discerning which resources complement their purposes, language learners are also inherently free to choose to work with texts that are most appropriate for their current language proficiency (Silc, 1998). By having the ability to self-select texts, ELLs can rely less on hearsay knowledge (e.g., explanations from teachers and other students about what the text means) and, instead, have a more genuine interaction with the texts. When ELLs do not have to attend to decoding texts, they are more easily able to focus on the more complex and necessary goals of authentic academic writing: clear communication about the meanings critically derived from and synthesized across texts.

Consider how a minor change in lesson design to include digital literacy practice can foster student writing success: Al-Jarf (2002) examined writing samples of ELLS who received non-traditional writing instruction that demanded and increased digital literacies. These students were tasked with independently exploring a multitude of online resources as evidence for academic writing and were compared to students who did not. Compared to the control, treatment students became more proficient, made fewer mistakes, and communicated more easily and fluently in post-instruction essays (2002). This demonstration suggests the possibility for digital literacies to function as a key component of authentic ELL participation in the academic inquiry and writing process. While we generally understand collaboration as positive, for ELLs who do not have autonomy in navigating and selecting texts online, it may be disheartening to face a teacher-selected text and have to rely on someone else for a translation. Digital literacies can help ELLs develop independence and take ownership of their understandings.

\subsection{Creating Digital Content}

It is important to recognize that ELLs who are skilled at navigating sources online and selecting appropriate tools must also be supported in order to continually progress with vocabulary acquisition and command. Language, a constituent of social interaction, is necessarily used for and cultivated through veritable communication. According to Brown (2007), technology facilitates ELLs opportunities to have "genuine, meaningful communication" (p. 54) in the target language. Although an analog classroom activity incorporating only pencil-and-paper might be an appropriate platform for sharing student illustra- tions and orally communicating design rationales in the target language, digital communication is more likely to reflect the social environment ELLs encounter outside of school and is thus, inherently more meaningful. In two studies on the effects of the integration of Facebook to encourage writing in secondary ELL classes, the research teams concluded that the online space was highly engaging for students and provided a supportive community to facilitate positive peer reinforcement of English use (Bigelow, Vanek, King, \& Abdi, 2017; Vanek, King, \& Bigelow, 2018). Moreover, writers on social media platforms are typically not governed by traditional demands for adherence to formal language usage. Consequently, by using these platforms, ELLs may become more confident in their command of English and may transfer this confidence to reading and writing English in other contexts.

By bringing the digital world essential to ELL daily lives, these students can "strengthen the connections between the English language and [their own] experiences and needs" in the real world (McClanahan, 2014, p. 24). Perhaps teachers can teach digital literacies to encourage language learners to locate and safely connect with online communities centered around personally relevant topics outside of school (Omerbašić, 2015). Students are empowered as media producers as well as critical viewers, who develop their English proficiency as well as self-identity in the collaborative, contextualized, and culturally inclusive learning environment. In Danzak's (2011) study, English learners in middle school created graphic stories that explored their family identities, cultural heritage, and immigration stories. This multimedia literacy project incorporated reading graphic novels, making journals, conducting interviews, as well as combining texts with family photos and other images using computer software.

\subsection{Communicating Digital Content}

Educators are using Web 2.0 tools to provide new modes of communication among teachers, ELLs, and the community. Doing so engages ELLs both within and outside the classroom in authentic, intellectual projects that support and deepen understandings. Effective use of mobile devices such as cell phones and tablets affords instant communication between teachers and ELLs. Moreover, it allows ELLs to share their products with a broad audience in the online community and to have their voices heard. This authenticity in their learning process serves as a motivator for ELLs to polish and publish their work.

Considerations when selecting instructional tools and creating assignments should also be made for software capabilities. Teachers and students should locate available software online that optimizes collaboration and reduces publishing overhead. Examining the relationship of English language learners' literacy skills (reading and writing) to online and offline content producing programs, Rahimi and Yadollahi (2017) found that 
the use of online software for digital storytelling was positively associated with higher Reading-Writing English test scores. Researchers selected software that helped students focus on their actual writing rather than requiring them to spend time searching for multimedia enhancements for aesthetic purposes. Thus, the online experience allows students to continuously collaborate to work through arising challenges that may present when creating content. Because of the ease in online peer-sharing, students are able to receive much more timely feedback than students who are working offline, in isolation.

Creating and sharing digital content can encourage students to develop a greater sense of pride in their work. For elementary students, digital storytelling can increase motivation by enhancing creativity (Liu, Tai, \& Liu, 2018). For older students, publishing student-authored blog posts is an effective pedagogical strategy that motivates language-learners to take greater care in proofreading their writing before submission and to feel excited about others' accessing their posts (Al-Qallaf \& Al-Mutairi, 2016). Experiencing positive affective responses to assignments is an incentive for students to learn.

Digital spaces that facilitate product sharing can also be a source of social empowerment for ELLs. ELLs who are digitally literate may be in a position to assist their native-speaking peers with internet navigation and software usage and may experience increased confidence. Blog posts used as a means to display academic writing knowledge can also serve language learners as a way to construct new relationships with one another and increase social capital through critical consideration of linguistic choices in anticipation of audience perceptions (Shin, 2014).

Teachers can teach digital literacies to encourage language learners to locate and safely connect with online communities centered around personally relevant topics outside of school. To illustrate, students who enjoy science fiction novels in their native language may scaffold their own target-language development by joining a wiki devoted to fan fiction. Therefore, communicating as members of an interesting online space can help facilitate students' confidence in using the lesser-known language to convey more complex ideas.

\section{Complexities of the Digital Divide}

Digital literacies offer unprecedented possibilities for ELLs to not only survive but thrive in the general classroom but can be limited, in practice, by the digital divide. This term has been traditionally understood as uneven "access to devices and Internet connectivity" (p. 17), but is now defined as "the disparity between students who use technology to create, design, build, explore, and collaborate and those who simply use technology to consume media passively" (Thomas, 2016, p. 18). This trend is evident in a 2018 PISA report, which suggested since 2012, with Internet access being commonplace, "socio- economically advantaged" students on average across most OECD countries reportedly spent equal or even less time online compared to disadvantaged students (Echazarra, 2018, p. 3); the traditional digital divide no longer remains.

Merely increasing the amount of the latest digital tools and digital media in classroom instruction does not guarantee effective use and quality learning outcomes. Echoed by the 2016 Pew Research Center report, digital literacies cannot empower students who merely have access to technology and digital spaces (Horrigan, 2016). In order to become digitally literate, ELLs must be expected to develop a high level of digital fluency that can provide a basis for educated discernment about how to "use technology as a tool to engage in creative, productive, lifelong learning rather than simply consuming passive content" (Thomas, 2016, p. 18). This requires effective usage guidance for classroom teachers, school curriculum, and school leadership and administration, calling for more research and actions in narrowing the digital use divide between ELLs and their native English speaking counterparts.

\section{Discussion and Future Research Directions}

We have established how digital literacy skills are necessitated for all by modern expectations and for ELLs in the United States by the autonomous learning and educational empowerment (Alexander et al., 2017) that results from their accessing the full potential of the Internet in order to critically evaluate information, as well as creating and communicating digital content (Spires \& Bartlett, 2012). Using the sociocultural perspective of second language acquisition (Lantolf \& Thorne, 2007) and an asset lens (Hakuta \& Garcia, 1989), practicing digital literacies in the classroom engages ELLs to develop as active participants who gain ownership of learning and the command of English through connecting school literacy with their funds of knowledge (Moll et al., 1992). This innovative teaching pedagogy is promising in addressing tensions between an English monolingual public school system in the United States and an increasing population of K-12 ELLs the system has been facing with (Gándara, 2015) by closing the achievement gaps between ELLs and their counterparts.

To ensure all students are able to take advantage of this learning, we suggest that teachers must also possess the knowledge and skills of digital literacies. Accordingly, educational researchers should examine factors that support teachers' utilization of digital literacies. For example, scholars might consider how teachers of ELLs can engage in ongoing professional development to secure knowledge of and guidance with emerging digital tools and contexts that can be used for both content instruction and literacy learning. Moreover, how to assess multiliteracies in a meaningful way that goes beyond the evaluation of operational skills needs to be addressed in the literature (Jacobs, 2013). Additionally, it may also be beneficial to 
understand the relationship of psychological characteristics, such as teacher self-efficacy and its contextual factors, with the effective deployment of online content.

At the school level, it is critical that leadership and administration can offer a supportive digital environment for both teachers and students. The ISTE Standards have foregrounded a framework for education leaders (2018) and administrators (2009) respectively when rethinking and creating "innovative" digital age learning environments. However, much research remains to be done in examining to what extent school leadership and administration 1) are aware of the importance of using technology to support teachers and ELLs; and 2) take actions to empower ELLs through digital literacies.

\section{Conflict of Interests}

The authors declare no conflict of interests.

\section{References}

Al-Jarf, R. (2002). Effect of online learning on struggling ESL college writers. Foreign Language Annals, 37(1), 46-56.

Al-Qallaf, C. L., \& Al-Mutairi, A. S. R. (2016). Digital literacy and digital content supports learning: The impact of blogs on teaching English as a foreign language. The Electronic Library, 34(3), 522-547. https://doi. org/10.1108/EL-05-2015-0076

Alexander, B., Becker, S. A., Cummins, M., \& Giesinger, C. H. (2017). Digital literacy in higher education, part II: An NMC horizon project strategic brief (Vol. 3/4, pp. 1-37). Austin, TX: The New Media Consortium. Retrieved from https://www.learntechlib.org/ $\mathrm{p} / 182086$

Apple, M. W., Au, W., \& Gandin, L. A. (2009). Introduction: Mapping critical education. In M. W. Apple, W. $\mathrm{Au}$, \& L. A. Gandin (Eds.), The Routledge international handbook of critical education (pp. 3-19). New York, NY: Routledge.

Au, K., \& Jordan, C. (1981). Teaching reasoning to Hawaiian children: Finding a culturally appropriate solution. In Culture and the bilingual classroom: Studies in classroom ethnography (pp. 139-152). Rowley, MA: Newbury House.

Barone, D. (2006). Narrowing the literacy gap: What works in high-poverty schools. New York, NY: Guilford.

Battelle for Kids. (2019). Framework for 21st century learning definitions. Retrieved from http://www. battelleforkids.org/networks/p21/frameworksresources

Bigelow, M., Vanek, J., King, K., \& Abdi, N. (2017). Literacy as social (media) practice: Refugee youth and native language literacy at school. International Journal of Intercultural Relations, 60, 183-197. https://doi.org/ 10.1016/j.ijintrel.2017.04.002

Boykin, A. W., Tyler, K. M., \& Miller, O. A. (2005). In search of cultural themes and their expressions in the dynamic life. Urban Education, 40, 521-549.

Broadband Commission for Sustainable Development. (2017). Working group on education: Digital skills for life and work. Paris: UNESCO. Retrieved from http://unesdoc.unesco.org/images/0025/002590/ 259013e.pdf

Brown, H. D. (2007). Teaching by principles: An interactive approach to language pedagogy (3rd ed.). White Plains, NY: Pearson Education.

Brown, M. (2018). Mind the gap: A critical guide to digital literacies. In G. Ubachs \& L. Konings (Eds.), The envisioning report for empowering universities (2nd ed., pp. 52-55). Maastricht: EADTU. Retrieved from https://tinyurl.com/envisioning-report

Capps, R., Fix, M., Murray, J., Ost, J., Passel, J. S., \& Herwantoro, S. (2005). The new demography of America's schools: Immigration and the no child left behind act. Washington, DC: Urban Institute.

Coleman, J. S., Campbell, E. Q., Hobson, C. J., McPartland, J., Mood, A. M., Weinfeld, F. D., \& York, R. L. (1966). Equality of educational opportunity. Washington, DC: Department of Health, Education and Welfare.

Cummins, J. (1996). Negotiating identities: Education for empowerment in a diverse society. Los Angeles, CA: Association for Bilingual Education.

Danzak, R. L. (2011). Defining identities through multiliteracies: EL teens narrate their immigration experiences as graphic stories. Journal of Adolescent \& Adult Literacy, 55(3), 187-196.

Delpit, L. (1988). The silenced dialogue: Power and pedagogy in educating other people's children. Harvard Educational Review, 58(3), 280-298.

Dore, L., Geraghty, A., \& O'Riordan, G. (2015). Towards a national digital skills framework for Irish higher education: Review and comparison of existing frameworks and models. University of Limerick. Retrieved from https://www.teachingandlearning.ie/wpcontent/uploads/NF-2016-Towards-a-NationalDigital-Skills-Framework-for-Irish-HigherEducation.pdf

Durrant, C., \& Green, B. (2000). Literacy and the new technologies in school education: Meeting the I(IT)eracy challenge? Australian Journal of Language and Literacy, 23(2), 89-108.

Echazarra, A. (2018). How has Internet use changed between 2012 and 2015? PISA in focus No. 83. Paris: OECD Publishing. https://doi.org/10.1787/ 1e912a10-en

Eller, R. G. (1989). Johnny can't talk, either: The perpetuation of the deficit theory in classrooms. The Reading Teacher, 42(9), 670-674.

Fairclough, N. (1989). Language and Power. London: Longman.

Ferrari, A. (2012). Digital competence in practice: An analysis of frameworks. Seville: Institute for Prospective Technological Studies, European Commission. Retrieved from http://www.ifap.ru/library/book522. pdf 
Fransecky, R. B., \& Debes, J. L. (1972). Visual literacy: A way to learn $-A$ way to teach. Washington, DC: AECT Publications.

Gándara, P. (2015). Charting the relationship of English learners and the ESEA: One step forward, two steps back. The Russell Sage Foundation Journal of the Social Sciences, 1(3), 112-128.

García, O., \& Kleifgen, J. (2018). Educating emergent bilinguals: Policies, programs, and practices for English learners. New York, NY: Teachers College Press.

Gay, G. (2002). Preparing for culturally responsive teaching. Journal of Teacher Education, 53(2), 106-116.

Gibbons, P. (2006). Bridging discourse in the ESL classroom. New York, NY: Continuum.

Gilster, P. (1997). Digital literacy. New York, NY: Wiley and Computer Publishing.

Haddix, M. (2016). Cultivating racial and linguistic diversity in literacy teacher education: Teachers like me. New York, NY: Routledge.

Hakuta, K., \& Garcia, E. E. (1989). Bilingualism and education. American Psychologist, 44(2), 374-379.

Heath, S. (1983). Ways with words: Language, life and work in communities and classrooms. Cambridge: Cambridge University Press.

Horrigan, J. B. (2016). Digital readiness gaps. Pew Research Center. Retrieved from http://www.pew internet.org/2016/09/20/2016/Digital-ReadinessGaps

International ICT Literacy Panel. (2002). Digital transformation: A framework for ICT literacy. Retrieved May 1, 2007, from Educational Testing Service website: http://www.ets.org/Media/Tests/ Information_and_Communication_Technology_ Literacy/ictreport.pdf

International Society for Technology in Education. (n.d.). ISTE standards. Eugene, OR: International Society for Technology in Education. Retrieved from https:// www.iste.org/standards

Jacobs, G. E. (2013). Designing assessments: A multiliteracies approach. Journal of Adolescent \& Adult Literacy, 56(8), 623-626.

Ladson-Billings, G. (2006). From the achievement gap to the education debt: Understanding achievement in US schools. Educational Researcher, 35(7), 3-12.

Lantolf, J., \& Thorne, S. L. (2007). Sociocultural theory and second language learning. Theories in second language acquisition (pp. 201-224). Mahwah, NJ: Lawrence Erlbaum.

Lemke, C. (2002). enGauge 21st Century Skills: Digital Literacies for a Digital Age. Naperville, IL: North Central Regional Educational Laboratory.

Liu, K., Tai, S. D., \& Liu, C. (2018). Enhancing language learning through creation: The effect of digital storytelling on student learning motivation and performance in a school English course. Educational Technology Research and Development, 66(4), 913-935. https://doi.org/10.1007/s11423-018-9592-z

Margolin, L. (2015). Unpacking the invisible knapsack:
The invention of white privilege pedagogy. Cogent Social Sciences, 1(1), 1-9.

McClanahan, L. (2014). Training using technology in the adult ESL classroom. Journal of Adult Education, 43(1), 22-27.

Mills, K. (2016). Literacy theories for the digital age: Social, critical, multimodal, spatial, material and sensory lenses. Tonawanda, NY: Multicultural Matters.

Moll, L., Amanti, C., Neff, D., \& Gonzalez, N. (1992). Funds of knowledge for teaching: Using a qualitative approach to connect homes and classrooms. Theory into Practice, 31(2), 132-141.

Musu-Gillette, L., de Brey, C., McFarland, J., Hussar, W., Sonnenberg, W., \& Wilkinson-Flicker, S. (2017). Status and Trends in the Education of Racial and Ethnic Groups 2017 (NCES 2017-051). Washington, DC: U.S. Department of Education, National Center for Education Statistics. Retrieved from https://nces.ed.gov/ pubs2017/2017051.pdf

National Assessment of Educational Progress. (2009). NAEP gaps. Retrieved from https://nces.ed.gov/ nationsreportcard/studies/gaps

National Center for Education Statistics. (2017a). Status and trends in the education of racial and ethnic groups 2017. Retrieved from https://nces.ed.gov/ pubsearch/pubsinfo.asp?pubid $=2017051$

National Center for Education Statistics. (2017b). Characteristics of public elementary and secondary school teachers in the United States: Results from the 2015-16 national teacher and principal survey. Retrieved from https://nces.ed.gov/pubsearch/ pubsinfo.asp?pubid=2017072rev

National Center for Education Statistics. (2018). English language learners in public schools. Retrieved from https://nces.ed.gov/programs/coe/indicator_ cgf.asp

National Governors Association Center for Best Practices. (2010). Common Core State Standards. Washington, DC: Common Core State Standards Initiative. Retrieved from http://www.corestandards.org/wpcontent/uploads/ELA_Standards1.pdf

National Governors' Association. (2017). Understanding the gaps: Who are we leaving behind-And how far? Washington, DC: NEA Education Policy and Practice \& Priority Schools Departments and Center for Great Public Schools. Retrieved from https://www.nea. org/assets/docs/18021-Closing_Achve_Gap_ backgrndr_7-FINAL.pdf

Norton, B. (2016). Identity and language learning: Back to the future. Vancouver: University of British Columbia.

Omerbašić, D. (2015). Literacy as a translocal practice: Digital multimodal literacy practices among girls resettled as refugees. Journal of Adolescent and Adult Literacy, 58, 472-481.

Rahimi, M., \& Yadollahi, S. (2017). Effects of offline vs. online digital storytelling on the development of EFL learners' literacy skills. Cogent Education, 4(1). 
https://doi.org/10.1080/2331186x.2017.1285531

Shin, D. (2014). Web 2.0 tools and academic literacy development in a US urban school: A case study of a second-grade English language learner. Language and Education, 28(1), 68-85. https://doi.org/ 10.1080/09500782.2013.771653

Silc, K. F. (1998). Using the world wide web with adult ESL learners. Center for adult English language acquisition. Retrieved from http://www.cal.org/caela/ esl_resources/digests/WWW.html

Spires, H., \& Bartlett, M. (2012). Digital literacies and learning: Designing a path forward (Friday Institute white paper series). Raleigh, NC: The William and Ida Friday Institute for Educational Innovation.

Thomas, S. (2016). Future ready learning: Reimagining the role of technology in education. Washington, DC: US Department of Education.

Toohey, S. (1999). Designing courses for higher education. Philadelphia, PA: Open University Press.

Tour, E. (2012). Rethinking technology use in ESL educa- tion. In B. Green \& C. Beavis (Eds.), Literacy in 3D: An integrated perspective in theory and practice. Camberwell: ACER Press.

US Department of Education. (2016). Non-regulatory guidance: English learners and title III of the elementary and secondary education act (ESEA), as amended by the every student succeeds act (ESSA). Washington, DC: US Department of Education.

Vanek, J., King, K., \& Bigelow, M. (2018). Social presence and identity: Facebook in an English language classroom. Journal of Language, Identity \& Education, 17(4), 236-254. https://doi.org/10.1080/15348458. 2018.1442223

Vygotsky, L. S. (1978). Mind in society. Cambridge, MA: Harvard University Press.

Zurkowski, P. G. (1974). The information service environment relationships and priorities (Report no. NCLISNPLIS-5). Washington, DC: National Commission on Libraries and Information Science. Retrieved from https://files.eric.ed.gov/fulltext/ED100391.pdf

\section{About the Authors}

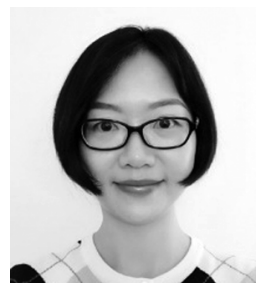

Chang Yuan is a fourth-year Doctoral Student in the TELS Literacy program in the College of Education at North Carolina State University. She received a bachelor's degree in economics from University of Western Ontario in Canada and a Master of Arts in teaching from North Carolina State University in the U.S. Her research interests include disciplinary literacy, ELL instruction, project-based inquiry, and the flipped classroom. Previously, Chang taught English and AP Economics in Beijing, China for four years.

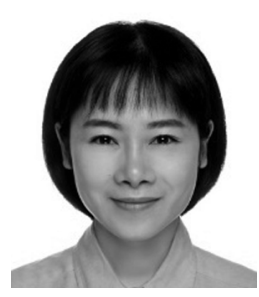

Lili Wang is a second-year Doctoral Student in the TELS Literacy program in the College of Education at North Carolina State University. She received a bachelor's degree in Administrative Management from Ningbo University in China and a Master of Arts in English Literature from Blekinge Institute of Technology in Sweden. Her research interests include technology use in English language learning classrooms, digital literacy, new literacies, and second language acquisition. Previously, Lili taught Business English at Wenzhou University for 10 years.

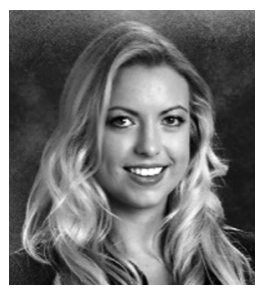

Jessica Eagle is a first-year Doctoral Student in the TELS Literacy program at North Carolina State University. Her research interests include the teaching of writing, new literacies, and student affect/emotion in the literature classroom. Previously, Jessica taught English Language Arts in a North Carolina public high school. She received bachelor's degrees in English and Psychology from the University of North Carolina at Chapel Hill and a Master of Arts in English Education from Teachers College, Columbia University. 